IOSR Journal of Pharmacy

ISSN: 2250-3013, www.iosrphr.org

\||| Volume 2 Issue 5 ||| Sep-Oct. 2012 ||| PP.12-19

\title{
Development and validation of stability indicating method for simultaneous estimation of ciprofloxacin hel and tinidazole using rp-uplc method
}

\author{
Sneha Jansari $\mathrm{K}^{1}$, Nirav Patel $\mathrm{B}^{* 2}$, Parag Patel $\mathrm{R}^{1}$, Nikita Patel $\mathrm{N}^{1}$, \\ Hemant Desai $\mathrm{T}^{2}$ \\ ${ }^{1}$ Department of Quality Assurance, Parul Institute of Pharmacy, Limda, TA. Waghodia, \\ Vadodara, Gujarat-391760 \\ ${ }^{2}$ Nirlife Healthcare (Healthcare Division of Nirma) Sachana (382150), Ahemdabad, Gujarat, India,
}

\begin{abstract}
This research manuscript describes simple, sensitive, accurate, precise and repeatable RP-UPLC method for the simultaneous determination of Ciprofloxacin $\mathrm{HCl}(\mathrm{CH})$ and Tinidazole (TZ) in tablet dosage form. The sample was analyzed by reverse phase C18 column (Purospher Star 100 $\times 2.1 \mathrm{~mm}, 2 \mu \mathrm{m}$ ) as stationary phase and Phosphate Buffer: Acetonitrile (80:20) as a mobile phase and pH 3.0 was adjusted by ortho-phosporic acid at a flow rate of $0.3 \mathrm{ml} / \mathrm{min}$. Quantification was achieved of Ciprofloxacin $\mathrm{HCl}$ at 278.5 $\mathrm{nm}$ and of Tinidazole at $317.5 \mathrm{~nm}$ with PDA detector. The retention time for Ciprofloxacin $\mathrm{HCl}$ and Tinidazole was found to be 1.71 and 2.22 minute respectively. The linearity for Ciprofloxacin $\mathrm{HCl}$ and Tinidazole was obtained in the concentration range of 3.125-43.75 $\mu \mathrm{g} / \mathrm{ml}$ and $3.75-52.5 \mu \mathrm{g} / \mathrm{ml}$ with mean accuracies of $99.77 \%$ and $99.75 \%$ respectively. The method was successfully applied to pharmaceutical formulation because no chromatographic interferences from tablet excipients were found. The precision (intraday, interday and repeatability) of method was found within limits. The method was validated as per ICH guidelines. Ciprofloxacin $\mathrm{HCl}$ and Tinidazole API and market formulation were subjected to acid and alkali hydrolysis, oxidation, thermal and photolytic forced degradation. The degraded product peaks were well resolved from the pure drug peak with significant difference in their retention time values. Besides, the peak purity of drug substance and drug product peak also confirmed the specificity of the methods with respect to the degradation products. In the forced degradation study Ciprofloxacin $\mathrm{HCl}$ and Tinidazole showed maximum degradation in oxidation stress study followed by less degradation in acidic condition. The developed isogradient method was simple, specific, sensitive, and economic and can be used for estimation of Ciprofloxacin $\mathrm{HCl}$ and Tinidazole in bulk and their combined tablet dosage form for routine analysis and stability studies.
\end{abstract}

Keywords-Ciprofloxacin HCl, Tinidazole, Method validation, RP-UPLC, Forced degradation

\section{INTRODUCTION}

Ciprofloxacin $\mathrm{HCl}(\mathrm{CH})$, an antibacterial drug is widely used to treat a number of infections including: infections of bones and joints, endocarditis, gastroenteritis, malignant otitis externa, respiratory tract infections, cellulitis, urinary tract infections, prostatitis, anthrax, chancroid among others. Chemically it is the monohydrochloride monohydrate salt of 1-cyclopropyl-6-fluoro-1, 4-dihydro-4-oxo-7-(1-piperazinyl)-3quinolinecarboxylic acid. And Tinidazole (TZ), an anti-parasitic drug chemically is 1-(2-ethylsulfonylethyl)-2methyl-5-nitro-imidazole. Both drugs are official in Indian pharmacopeia, British Pharmacopeia and United States Pharmacopeia. The combination of $\mathrm{CH}$ and $\mathrm{TZ}$ is widely used in treatment of microbial infections. Literature search reveals that various analytical methods like UV-visible spectrophotometry (Rajesh Sharma et al.,2011); (Maliwal D et al.,2008); (Mashru R.C et al., 1998); Differential Pulse Polarography (Salvi V S et al., 2010); HPLC (M. S Bhatia et al.,1999); HPLC (Sani A. Ali et al.1,2011) have been reported for estimation of $\mathrm{CH}$ and $\mathrm{TZ}$ in their individual and combined dosage forms.. Literature survey describes that there is no reported method for degradation studies of Ciprofloxacin $\mathrm{HCl}$ and Tinidazole in various stress condition like alkaline, cidic, oxidative and thermal and photo degradation by RP-UPLC method. Therefore it was thought of interest to study the stability of Ciprofloxacin $\mathrm{HCl}$ and Tinidazole in various stress condition (alkaline, acidic, oxidative,

\footnotetext{
${ }^{1} \mathrm{CH}-$ Ciprofloxacin $\mathrm{HCl}-\mathrm{CH},{ }^{2}$ Tinidazole- TZ

${ }^{3}$ RP-UPLC- Reverse Phase Ultra Performance Liquid Chromatography
} 
Thermal and photo degradation) by RP-UPLC method. The chemical structure of Ciprofloxacin $\mathrm{HCl}$ and Tinidazole are shown in Fig.1 and Fig. 2.

\section{MATERIALS \& METHODS}

\subsection{Apparatus}

The chromatography was performed on a Water (Acquity) RP-UPLC instrument equipped with PDA detector and Empower 2 software (Version- EMPOWER SOFTWARE 2 Build 2154); Purospher Star C18 column $(100 \mathrm{~mm} \times 2.1 \mathrm{~mm}$ id, $2 \mu \mathrm{m}$ particle size, Merck, Germany) was used as stationary phase. Mettler Toledo analytical balance (Germany), pH meter from Lab India, an ultrasonic cleaner (Frontline FS 4, Mumbai, India), Hot air oven (Lab India), Photo stability chamber were used in the study.

\subsection{Reagents and materials}

Ciprofloxacin $\mathrm{HCl}$ and Tinidazole bulk powder was obtained from Nonlife Healthcare, division of Norma. Ahmedabad, India. Marketed Product (NIRCIP-TZ Tablet,

Batch No: 8F10042) was procured from the Nirlife Healthcare. Label claim of NIRCIP-TZ is Ciprofloxacin HCl $-500 \mathrm{mg}$ and Tinidazole-600 mg. Acetonitrile, KH2PO4 (Finar Reagent, Ahmedabad, India) used were of HPLC grade. Whatman filter paper no. 41. (Whatman International Ltd., England), Orthophosphoric acid(AR), Sodium Hydroxide, Hydrochloric acid, Hydrogen peroxide (30\%) from Merck, specialties Pvt Ltd, Mumbai, India were used in the study.

\subsection{Chromatographic Condition}

Separation was achieved by using Purospher Star C18 column $(100 \mathrm{~mm} \times 2.1 \mathrm{~mm}$ id, $2 \mu \mathrm{m}$ particle size, Marck, Germany) as stationary phase with Phosphate Buffer: Acetonitrile $(80: 20)$ as a mobile phase and $\mathrm{P}^{\mathrm{H}}$ of 3.0 were adjusted by ortho-phosphoric acid at a flow rate of $0.3 \mathrm{ml} / \mathrm{min}$ and $6 \mathrm{~min}$ run time. Quantification was achieved of Ciprofloxacin $\mathrm{HCl}$ at $278.5 \mathrm{~nm}$ and of Tinidazole at $317.5 \mathrm{~nm}$ with PDA detector at $25 \pm 2^{\circ} \mathrm{C}$ temperature condition and $2 \mu 1$ injection volume.

\subsection{Preparation of mobile phase}

Accurately Weigh $6.8 \mathrm{gm}$ of Potassium dihydrogen ortho phosphate was transferred into $1000 \mathrm{ml}$ volumetric flask. Approximately $800 \mathrm{ml}$ of water was added into the volumetric flask and sonicated. Volume was made up to $1000 \mathrm{ml}$ with water. From this buffer solution $800 \mathrm{ml}$ of solution was withdrawn and mixed with $200 \mathrm{ml}$ of Acetonitrile into separated $1000 \mathrm{ml}$ volumetric flask to make a mobile phase ratio buffer: Acetonitrile $(80: 20 \% \mathrm{v} / \mathrm{v}) . \mathrm{P}^{\mathrm{H}}$ of 3.0 was adjusted by using ortho-phosphoric acid of mobile phase. This mobile phase used as diluents also throughout study.

\subsection{Preparation of standard solution}

\subsubsection{Preparation of standard stock solution of Ciprofloxacin $\mathrm{HCl}(\mathrm{CH})(\mathrm{S1})$}

An accurately weighed $100 \mathrm{mg}$ of quantity of $\mathrm{CH}$ reference standard was transferred into $100 \mathrm{ml}$ volumetric flask, dissolved in $50 \mathrm{~mL}$ mobile phase and sonicated. After this it was diluted up to mark with mobile phase to get concentration of $\mathrm{CH}(1000 \mu \mathrm{g} / \mathrm{mL})$.

\subsubsection{Working standard solution of $\mathrm{CH}(\mathrm{WI})$}

$250 \mu \mathrm{g} / \mathrm{ml}$ of $\mathrm{CH}$ working standard solution was prepared by diluting $25 \mathrm{ml}$ from above stock solution, made up to $100 \mathrm{ml}$ with mobile phase into $100 \mathrm{ml}$ volumetric flask.

\subsubsection{Preparation of Tinidazole (TZ) stock solution (S2)}

An accurately weighed $100 \mathrm{mg}$ of quantity of TZ reference standard was transferred into $100 \mathrm{ml}$ volumetric flask, dissolved in $50 \mathrm{~mL}$ mobile phase and sonicated. After this it was diluted up to mark with mobile phase to get concentration of TZ $(1000 \mu \mathrm{g} / \mathrm{mL})$.

\subsubsection{Working standard solution of TZ (W2)}

$300 \mu \mathrm{g} / \mathrm{ml}$ of TZ working standard solution was prepared by diluting $30 \mathrm{ml}$ from above stock solution, made up to $100 \mathrm{ml}$ with mobile phase into $100 \mathrm{ml}$ volumetric flask.

\subsection{Calibration curve of $\mathrm{CH}$ and $\mathrm{TZ}$ \\ 2.6.1 Ciprofloxacin $\mathrm{HCl}$}

Aliquots of working standard solution $(250 \mu \mathrm{g} / \mathrm{ml})$ of $\mathrm{CH}(1.25,2.5,5,7.5,10,12.5,15$ and $17.5 \mathrm{ml})$ were transferred into a series of $100 \mathrm{ml}$ volumetric flasks and volume was adjusted to the mark with mobile phase to get concentrations $3.125,6.25,12.5,18.75,25,31.25,37.50$ and $43.75 \mu \mathrm{g} / \mathrm{ml}$. Solutions were injected into the system with stated chromatographic conditions.. The graph of area of peak obtained versus respective concentration was plotted. The mean area and its standard deviation were calculated.

\subsubsection{Tinidazole}

Aliquots of working standard solution $(300 \mu \mathrm{g} / \mathrm{ml})$ of TZ $(1.25,2.5,5,7.5,10,12.5,15$ and $17.5 \mathrm{ml})$ were transferred into a series of $100 \mathrm{ml}$ volumetric flasks and volume was adjusted to the mark with mobile phase to get concentrations $3.75,7.5,15,22.5,30,37.5,45$ and $52.5 \mu \mathrm{g} / \mathrm{ml}$ of TZ. Solutions were injected into the 
system with stated chromatographic conditions. The graph of area of peak obtained versus respective concentration was plotted. The mean area and its standard deviation were calculated.

\subsection{Preparation of Marketed sample solution for Assay}

Simultaneous estimation of $\mathrm{CH}$ and $\mathrm{TZ}$ in marketed tablet dosage form (NIRCIP-TZ) containing label claim of CH-500 mg and TZ-600mg was carried out. In this assay procedure, 20 tablets of formulation were crushed and ground to a fine powder. Powder equivalent to $25 \mathrm{mg}$ of $\mathrm{CH}$ and $30 \mathrm{mg}$ of TZ was transferred to a $100 \mathrm{ml}$ volumetric flask containing about $75 \mathrm{ml}$ of mobile phase, dissolved and sonicated for $30 \mathrm{~min}$. The solution was diluted up to the mark with mobile phase. The solution was filtered through Whatmann filter paper No. 41 and residue was washed with mobile phase. Accurately measured $1.0 \mathrm{ml}$ of solution was transferred to $10 \mathrm{ml}$ volumetric flask, diluted up to the mark with mobile phase to get final working concentration of $\mathrm{CH}(25$ $\mu \mathrm{g} / \mathrm{ml})$ and $\mathrm{TZ}(30 \mu \mathrm{g} / \mathrm{ml})$. A sample solution was injected under the operating chromatographic condition as described above and responses were recorded.

\subsection{Method validation}

The method was validated in compliance with ICH guidelines. (Q 2 B)

\subsubsection{Linearity and Range}

The linearity response was determined by analyzing 8 independent levels of calibration curve in the range of $3.125-43.75 \mu \mathrm{g} / \mathrm{ml}$ and $3.75-52.5 \mu \mathrm{g} / \mathrm{ml}$ for $\mathrm{CH}$ and $\mathrm{TZ}$ respectively. Plot the calibration curve of Area versus respective concentration and find out correlation co-efficient and regression line equation for $\mathrm{CH}$ and TZ.

\subsubsection{Precision}

\subsubsection{Repeatability}

It was determined by analyzing $\mathrm{CH}(25 \mu \mathrm{g} / \mathrm{ml})$ and $\mathrm{TZ}(30 \mu \mathrm{g} / \mathrm{ml})$ seven times in mixture. The areas of seven replicate injections were measured and \% RSD was calculated.

\subsubsection{Intraday precision}

For intraday, $\mathrm{CH}$ and $\mathrm{TZ}$ in the range of $3.125-43.75 \mu \mathrm{g} / \mathrm{ml}$ and $3.75-52.5 \mu \mathrm{g} / \mathrm{ml}$ were analyzed three times on the same day and \% C.V. was calculated.

\subsubsection{Interday precision}

For interday, $\mathrm{AC}$ and $\mathrm{OM}$ in the range of $3.125-43.75 \mu \mathrm{g} / \mathrm{ml}$ and $3.75-52.5 \mu \mathrm{g} / \mathrm{ml}$ were analyzed on three different days and \% C.V. was calculated.

\subsubsection{Accuracy}

The accuracy of the method was determined by calculating the recoveries of $\mathrm{CH}$ and $\mathrm{TZ}$ by the standard addition method. Known amounts of standard solutions of $\mathrm{CH}$ and $\mathrm{TZ}$ were at added at 80, 100 and $120 \%$ level to prequantified sample solutions of $\mathrm{CH}$ and TZ $(25$ and30 $\mu \mathrm{g} / \mathrm{ml}$ respectively). The amounts of $\mathrm{CH}$ and $\mathrm{TZ}$ were estimated by applying obtained values to the respective regression line equations, the solution was filtered through $0.45 \mu$ Millipore PVDF filter; filtrate was collected after discarding first few ml. Each sample was prepared in triplicate at each level and injected. The chromatograms were recorded and from the peak area of drug, \% recovery was calculated from regression equation of the calibration curve.

\subsubsection{Limit of detection and Limit of quantification}

The limit of detection (LOD) and limit of quantitation (LOQ) of the method were determined by standard deviation of response and slope method.

\section{RESULTS AND DISCUSSION}

To optimize the RP-UPLC parameters, several mobile phase compositions were tried. A satisfactory separation and good peak symmetry for Ciprofloxacin $\mathrm{HCl}$ and Tinidazole were obtained with a mobile phase comprising of Phosphate Buffer: Acetonitrile (80:20) and $\mathrm{P}^{\mathrm{H}}$ of 3.0 adjusted by ortho-phosphoric acid at a flow rate of $0.3 \mathrm{ml} / \mathrm{min}$ to get better reproducibility and repeatability. Quantification was achieved of Ciprofloxacin $\mathrm{HCl}$ at $278.5 \mathrm{~nm}$ and of Tinidazole at $317.5 \mathrm{~nm}$ with PDA detector. The retention time for Ciprofloxacin $\mathrm{HCl}$ and Tinidazole were found to be 1.7 and $2.2 \mathrm{~min}$, respectively. Linear correlation was obtained between peak area versus concentrations of Ciprofloxacin $\mathrm{HCl}$ and Tinidazole (Figure 3) in the concentration ranges of 3.125$43.75 \mu \mathrm{g} / \mathrm{ml}$ and $3.75-52.5 \mu \mathrm{g} / \mathrm{ml}$ with mean accuracies $99.77 \%$ and $99.75 \%$ The mean recoveries obtained were $99.77 \%$ and $99.75 \%$ for Ciprofloxacin $\mathrm{HCl}$ and Tinidazole, respectively, Table 1 and 2 which indicates accuracy of the proposed method. The $\%$ RSD values for $\mathrm{CH}$ and $\mathrm{TZ}$ were found to be $<2 \%$, which indicates that the proposed method is repeatable. The low \% RSD values of interday $(0.08-0.46 \%$ and $0.22-0.4 \%)$ and intraday $(0.08-0.62 \% \%$ and $0.26-0.44 \% \%)$ variations for $\mathrm{CH}$ and $\mathrm{TZ}$, respectively, reveal that the proposed method is precise. LOD values for Ciprofloxacin $\mathrm{HCl}$ and Tinidazole were found to be $0.063 \mu \mathrm{g} / \mathrm{ml}$ and $0.01 \mu \mathrm{g} / \mathrm{ml}$ respectively and LOQ values for Ciprofloxacin $\mathrm{HCl}$ and Tinidazole were found to be $0.193 \mu \mathrm{g} / \mathrm{ml}$ and $0.030 \mu \mathrm{g} / \mathrm{ml}$ respectively (Table 1 ). The results of system suitability testing are given in (Table 3 ). The amount of Ciprofloxacin $\mathrm{HCl}$ and Tinidazole present in the marketed sample solutions were determined by plotting the 
responses into the regression equations of the calibration curve for Ciprofloxacin $\mathrm{HCl}$ and Tinidazole, respectively and the results obtained were comparable with the corresponding labeled claim (Table 1).

\subsection{Degradation study of $\mathrm{CH}$ and $\mathrm{TZ}$ in $0.1 \mathrm{~N} \mathrm{HCl} \mathrm{at} 70^{\circ} \mathrm{C}$ for 4 hours in reflux condition.}

It showed multiple peaks of degradation products. Major degradation peak was found at 0.6 min for $\mathrm{CH}$ and at $1.0 \mathrm{~min}$ for TZ in both drug product and drug substance. $\mathrm{CH}$ and $\mathrm{TZ}$ peak was observed at retention time $1.7 \mathrm{~min}$ and 2.3 min respectively. (Figure 4) The \% drug degradation observed of $\mathrm{CH}$ and $\mathrm{TZ}$ was $11.98 \%$ and $8.37 \%$ respectively.

\subsection{Degradation study of $\mathrm{CH}$ and $\mathrm{TZ}$ in $0.1 \mathrm{~N} \mathrm{NaOH}$ at $70^{\circ} \mathrm{C}$ for 4 hours in reflux condition.}

It showed two peaks at retention time $0.9 \mathrm{~min}$ and 1.3 for $\mathrm{CH}$ in both drug product and drug substance. The degradation peak for TZ was found at $1.1 \mathrm{~min}$ in both drug substance and drug sample (Figure 5). The \% drug degradation observed of $\mathrm{CH}$ and $\mathrm{TZ}$ was $17.54 \%$ and $27.72 \%$ respectively. This shows that Tinidazole is very prone to alkaline hydrolysis as compare to $\mathrm{CH}$, and significant degradation of both the drugs was observed. 3.3 Oxidation degradation study of $\mathrm{CH}$ and $\mathrm{TZ}$ in $3 \% \mathrm{H}_{2} \mathrm{O}_{2}$ at $70^{\circ} \mathrm{C}$ for about 1 hour in reflux condition.

Sample and drug substances were treated with $3 \%$ solution of hydrogen peroxide and kept in water bath at $70^{\circ} \mathrm{C}$ in reflux condition for about 1 hour. There was major degradation peak was found at 0.7 min for $\mathrm{CH}$ and $\mathrm{TZ}$ in drug substance and drug product. Another degraded peak for $\mathrm{CH}$ was found at $1.3 \mathrm{~min}$ and for $\mathrm{TZ}$ at $1.0 \mathrm{~min}$. the $\%$ degradation observed of $\mathrm{CH}$ and $\mathrm{TZ}$ was $35 \%$ and $41.97 \%$ respectively. (Figure 6). From this it is observed that TZ showed maximum degradation in peroxide degradation condition.

\subsection{Thermal Degradation study of $\mathrm{CH}$ and $\mathrm{TZ}$ at $60^{\circ} \mathrm{C}$ for about $24 \mathrm{hrs}$}

Thermal degradation of $\mathrm{CH}$ and $\mathrm{TZ}$ at $60^{\circ} \mathrm{C}$ for about $24 \mathrm{hrs}$ in hot air oven was carried out. There were three degradation peak was found at $0.9,1.0$ and $1.3 \mathrm{~min}$ for $\mathrm{CH}$ in drug product. Degradation of TZ was found out at $0.9 \mathrm{~min}$ in both TZ-API and drug product. \%Degradation of $\mathrm{CH}$ and $\mathrm{TZ}$ was found to be $0.87 \%$ and $0.98 \%$ respectively (Figure 7 ).

\subsection{Photolytic Degradation study of $\mathrm{CH}$ and $\mathrm{TZ}$}

Sample and drug substances were exposed to energy of 1.2 million lux hrs fluorescent light and $200 \mathrm{~W} / \mathrm{m}^{2}$ of UV for about 7 days. There were minor degradation peaks found at $0.9 \mathrm{~min}$ and $1.0 \mathrm{~min}$ for $\mathrm{CH}$ in drug substance and drug product. Degradation peak for TZ was found at 1.4 min. \%degradation of $\mathrm{CH}$ and $\mathrm{TZ}$ was found at $10.11 \%$ for $\mathrm{CH}$ and $11.95 \%$ for TZ. $\mathrm{CH}$ showed least degradation in photolytic condition.(Figure $8)$.

\section{CONCLUSION}

Stability indicating RP-UPLC methods for estimation of Ciprofloxacin $\mathrm{HCl}$ and Tinidazole in their solid dosage form was established and validated as per the ICH guidelines. The forced degradation study and peak purity data confirmed that there was no merging between peaks of active ingredients and any other degradation products as well as other additives. Hence the specificity of the proposed method was established. The linearity of developed method was achieved in the range of $3.125-43.75 \mu \mathrm{g} / \mathrm{ml}$ for Ciprofloxacin $\mathrm{HCl}$ $\left(\mathrm{r}^{2}=0.9999\right)$ and $3.75-52.5 \mu \mathrm{g} / \mathrm{ml}$ for Tinidazole $\left(\mathrm{r}^{2}=0.9999\right)$. The percentage recovery of drug was achieved in the range of $98-101 \%$ which was within the acceptance criteria. The percentage RSD was NMT $2 \%$ which proved the precision of the developed method. Different degradation products were found for drug substance and drug product in acidic, alkaline, oxidative, thermal and photolytic force degradation. Peak of Degraded products were not interfering with the main drug peak of Ciprofloxacin $\mathrm{HCl}$ and Tinidazole. Thus these degradation products have not been identified. The developed method is simple, sensitive, rapid, linear, precise, rugged, accurate, specific, and robust. Hence it can be used for the routine analysis of Ciprofloxacin $\mathrm{HCl}$ and Tinidazole in their bulk and tablet dosage form in quality control laboratory and stability studies.

\section{ACKNOWLEDGEMENT}

The authors are thankful to Nirlife HealthCare, Ahmedabad, Gujarat, India for providing a Sample and facilities for research. The authors are highly thankful to Parul Institute of Pharmacy, Limda, and Gujarat, India for supporting to carry out the work. 


\section{REFERENCES}

[1]. Bhatia M.S, Kaskhedikar S.G, Chaturvedi S.C, "High performance chromatographic estimation of Ciprofloxacin hydrochloride and Tinidazole from Tablet', International Journal of Pharmaceutical sciences, SeptemberOctober 1999, pp 311-312.

[2]. British Pharmacopoeia, $6^{\text {th }}$ Edn, British Pharmacopoeia commission, 2009, Volume I \& II, pp 1381.

[3]. ICH Harmonized Tripartite Guideline, Validation of Analytical Procedures: Text and Methodology Q 2 (R1), Current Step 4 version, November 2005, pp 6-13.

[4]. Indian Pharmacopoeia, the Indian Pharmacopoeia Commission, Govt. of India Ministry of Health and Family Welfare, 2007, Volume II and III, pp 1186.

[5]. Sharma R, Pathodiya G, Mishra G. P, Sainy J, "A Novel Spectrophotometric Methods for Quantitative Determination of Ciprofloxacin Hydrochloride and Tinidazole in Tablets using Hydrotropic Solubilizing Agent", Journal of Pharmacy Research, 2011, 4(3), 859-861.

[6]. Salvi V.S, Sathe P.A, Rege P.V, "Determination of Tinidazole and Ciprofloxacin Hydrochloride in Single Formulation Tablet using Differential Pulse Polarography", J Anal Bioanal Techniques, 2010, 1, 110.

[7]. Sani A.A, Chijioke C. and Mohammed Ilyas, "High performance chromatography (HPLC) method Development and Validation Indicating Assay for Ciprofloxacin Hydrochloride, Journal of Applied Pharmaceutical Science, 2011, 1 (8), 239-243.

[8]. Satinder Ahuja, Handbook of modern pharmaceutical analysis, separation science and technology, vol-3, Academic Press, 2001, pp 98-113.

[9]. Kothapalli U, Pradhan K, “A Validated UV-Spectrophotometric Method for the Estimation of Tinidazole in Bulk and Pharmaceutical Dosage Form", International Journal of Pharmaceutical \& Biological Archives, 2011, 2(4), 1152-1156.

[10]. United States Pharmacopoeia, Rockville MD 20852, United States Convention Inc, USP 30-NF25, 1737.

Table 1: Regression analysis data and summary of validation parameter for the proposed RP-UPLC method

\begin{tabular}{|c|c|c|c|}
\hline Parameters & Acceptance Criteria & Ciprofloxacin $\mathrm{HCl}$ & Tinidazole \\
\hline Linearity Range $(\mu \mathrm{g} / \mathrm{ml})$ & & $3.125-43.75$ & $3.75-52.5$ \\
\hline Slope & & 10935 & 4388 \\
\hline Intercept & & -12303 & 973.7 \\
\hline Correlation coefficient & $>0.995$ & 0.9999 & 0.9999 \\
\hline $\begin{array}{l}\text { Regression equation } \\
\mathrm{y}=\mathrm{mx}+\mathrm{c}\end{array}$ & & $Y=10935 x-12303$ & $Y=4388 x+973.7$ \\
\hline $\operatorname{LOD}^{\mathrm{a}}(\mu \mathrm{g} / \mathrm{ml})$ & $\mathrm{S} / \mathrm{N}>2$ or 3 & 0.063 & 0.01 \\
\hline $\mathrm{LOQ}^{\mathrm{b}}(\mu \mathrm{g} / \mathrm{ml})$ & $\mathrm{S} / \mathrm{N}>10$ & 0.193 & 0.0304 \\
\hline Accuracy & & $99.77 \%$ & $99.75 \%$ \\
\hline $\begin{array}{l}\text { Repeatability (\% RSD, } n= \\
\text { 6) }\end{array}$ & & $0.8 \%$ & $0.4 \%$ \\
\hline \multicolumn{4}{|l|}{ Precision (\%RSD) } \\
\hline Intraday $(n=3)$ & & $0.12-0.67 \%$ & $0.13 \%-0.87 \%$ \\
\hline Interday $(n=3)$ & & $0.12-0.87 \%$ & $0.12-0.82 \%$ \\
\hline Accuracy & $\begin{array}{l}\text { Recovery } 98-102 \% \\
\text { (individual) }\end{array}$ & $98.7 \%-99.2 \%$ and & $99.5 \%-99.7 \%$ \\
\hline \multirow[t]{2}{*}{ Specificity } & $\begin{array}{l}\text { No interference from } \\
\text { blank, placebo and } \\
\text { degradation product } \\
\text { and stress sample }\end{array}$ & No interference & No interference \\
\hline & $\begin{array}{l}\text { Peak purity index > } \\
0.999\end{array}$ & No Purity Error & No Purity Error \\
\hline$\%$ Assay & - & $99.12 \%$ & $97.21 \%$ \\
\hline
\end{tabular}

$\mathrm{a}=$ Limit of Detection, $\mathrm{b}=$ Limit of Quantitation, $\mathrm{c}=$ relative standard deviation 
Development and validation of stability indicating method for simultaneous estimation of...

Table 2: Recovery data for the proposed method

\begin{tabular}{|c|c|c|c|c|c|c|c|c|c|c|c|c|c|c|}
\hline \multirow[t]{2}{*}{ Levels } & \multicolumn{2}{|c|}{$\begin{array}{l}\text { Test } \\
\text { Solution } \\
\mu \mathrm{g} / \mathrm{mL}\end{array}$} & \multicolumn{2}{|c|}{$\begin{array}{l}\text { Solution } \\
\text { added in } \\
\mu \mathrm{g} / \mathrm{mL}\end{array}$} & \multicolumn{2}{|c|}{$\begin{array}{l}\text { Total } \\
\text { amount } \\
\text { of drug } \\
\text { in } \mu \mathrm{g} / \mathrm{mL}\end{array}$} & \multicolumn{2}{|c|}{$\begin{array}{l}\text { Amount } \\
\text { Recovered }\end{array}$} & \multicolumn{2}{|c|}{$\begin{array}{l}\% \text { Amount } \\
\text { Recovered }\end{array}$} & \multicolumn{2}{|c|}{$\begin{array}{l}\% \quad \text { Mean } \\
\text { Recovered }\end{array}$} & \multicolumn{2}{|c|}{$\%$ RSD } \\
\hline & $\mathbf{C H}$ & $\mathbf{T Z}$ & $\mathbf{C H}$ & $\mathbf{T Z}$ & CH & $\mathbf{T Z}$ & CH & $\mathbf{T Z}$ & $\mathbf{C H}$ & $\mathbf{T Z}$ & $\mathbf{C H}$ & $\mathrm{TZ}$ & $\mathbf{C H}$ & $\mathbf{T Z}$ \\
\hline \multirow{3}{*}{$80 \%$} & 25 & 30 & 20 & 24 & 45 & 54 & 44.6 & 53.8 & 99.1 & 99.6 & \multirow{3}{*}{98.7} & \multirow{3}{*}{99.7} & \multirow{3}{*}{0.27} & \multirow{3}{*}{0.5} \\
\hline & 25 & 30 & 20 & 24 & 45 & 54 & 44.3 & 53.6 & 98.4 & 99.2 & & & & \\
\hline & 25 & 30 & 20 & 24 & 45 & 54 & 44.4 & 53.1 & 98.6 & 100.3 & & & & \\
\hline \multirow{3}{*}{$100 \%$} & 25 & 30 & 25 & 30 & 50 & 60 & 49.6 & 59.7 & 99.2 & 99.5 & \multirow{3}{*}{99.6} & \multirow{3}{*}{99.7} & \multirow{3}{*}{0.6} & \multirow{3}{*}{0.4} \\
\hline & 25 & 30 & 25 & 30 & 50 & 60 & 49.7 & 60.1 & 99.4 & 100.2 & & & & \\
\hline & 25 & 30 & 25 & 30 & 50 & 60 & 50.2 & 59.8 & 100.4 & 99.6 & & & & \\
\hline \multirow{3}{*}{$120 \%$} & 25 & 30 & 30 & 36 & 55 & 66 & 54.8 & 65.3 & 99.6 & 98.9 & \multirow{3}{*}{99.2} & \multirow{3}{*}{99.5} & \multirow{3}{*}{0.3} & \multirow{3}{*}{0.72} \\
\hline & 25 & 30 & 30 & 36 & 55 & 66 & 54.6 & 65.6 & 99.27 & 99.3 & & & & \\
\hline & 25 & 30 & 30 & 36 & 55 & 66 & 54.4 & 66.2 & 98.9 & 100.3 & & & & \\
\hline
\end{tabular}

Table 3: Data for system suitability test for $\mathrm{CH}$ and $\mathrm{TZ}$ in different degradation condition

\begin{tabular}{|c|c|c|c|c|c|c|c|c|c|c|c|}
\hline \multirow{4}{*}{$\begin{array}{l}\text { Sr. } \\
\text { No. }\end{array}$} & \multirow{4}{*}{$\begin{array}{l}\text { System } \\
\text { Suitability } \\
\text { Test }\end{array}$} & \multicolumn{10}{|c|}{ Observed Values } \\
\hline & & \multicolumn{10}{|c|}{ Degradation } \\
\hline & & \multicolumn{2}{|c|}{ Alkaline } & \multicolumn{2}{|c|}{ Acidic } & \multicolumn{2}{|c|}{ Oxidative } & \multicolumn{2}{|c|}{ Photolytic } & \multicolumn{2}{|c|}{ Thermal } \\
\hline & & $\mathbf{C H}$ & $\mathbf{T Z}$ & $\mathbf{C H}$ & $\mathbf{T Z}$ & $\mathbf{C H}$ & $\mathbf{T Z}$ & $\mathbf{C H}$ & $\mathbf{T Z}$ & $\mathbf{C H}$ & $\mathbf{T Z}$ \\
\hline 1 & $\begin{array}{l}\text { Resolution } \\
\text { (Rs) }\end{array}$ & & 6.15 & & 5.49 & & 6.07 & & 5.75 & & 5.98 \\
\hline 2 & $\begin{array}{l}\text { Number of } \\
\text { plates }(\mathrm{N})\end{array}$ & 9428 & 11084 & 9425 & 11354 & 9428 & 10265 & 9497 & 11198 & 9135 & 11652 \\
\hline 3 & $\begin{array}{l}\text { Tailing } \\
\text { factor }(\mathrm{T})\end{array}$ & 1.2 & 1.05 & 1.21 & 1.098 & 1.3 & 1.07 & 1.15 & 1.02 & 1.447 & 1.05 \\
\hline
\end{tabular}

Table 4: \% Degradation of $\mathrm{CH}$ and $\mathrm{TZ}$ in different conditions

\begin{tabular}{|c|c|c|c|c|c|c|c|c|c|}
\hline \multirow[t]{2}{*}{$\begin{array}{l}\text { Degradation } \\
\text { condition }\end{array}$} & \multirow[t]{2}{*}{ Time } & \multicolumn{2}{|l|}{ Area } & \multicolumn{2}{|c|}{$\begin{array}{l}\text { Conc. } \\
(\mu \mathrm{g} / \mathrm{ml})\end{array}$} & \multicolumn{2}{|c|}{$\%$ Potency } & \multicolumn{2}{|c|}{$\begin{array}{l}\% \\
\text { Degradation }\end{array}$} \\
\hline & & $\mathbf{C H}$ & $\mathbf{T Z}$ & $\mathbf{C H}$ & $\mathbf{T Z}$ & $\mathbf{C H}$ & $\mathbf{T Z}$ & $\mathbf{C H}$ & TZ \\
\hline \multirow{2}{*}{$\begin{array}{l}\text { Acidic/ } 0.1 \quad \mathrm{~N} \\
\mathrm{HCl} / 70^{\circ} \mathrm{C} / \text { Reflux/ } \\
\text { 4hr/ Solution }\end{array}$} & 0 & 1059400 & 432238 & 24.99 & 29.98 & 99.99 & 99.96 & \multirow[b]{2}{*}{11.98} & \multirow[b]{2}{*}{8.37} \\
\hline & $4 \mathrm{hrs}$ & 932505 & 396189 & 22.0 & 27.48 & 88.01 & 91.62 & & \\
\hline \multirow{2}{*}{$\begin{array}{l}\text { Alkaline/ } \quad 0.1 \mathrm{~N} \\
\mathrm{NaOH} / \text { Reflux } / 70^{\circ} \mathrm{C} / \\
4 \mathrm{hr} / \text { Solution }\end{array}$} & 0 & 1059401 & 432400 & 24.99 & 29.99 & 99.99 & 99.99 & \multirow{2}{*}{17.54} & \multirow{2}{*}{27.72} \\
\hline & $4 \mathrm{hrs}$ & 873532 & 312510 & 20.61 & 21.68 & 82.45 & 72.27 & & \\
\hline \multirow{2}{*}{$\begin{array}{l}\text { Oxidative/ } 3 \% \\
\mathrm{H} 2 \mathrm{O} 2 / \mathrm{Reflux} / 1 \mathrm{hr} / \\
\text { Solution }\end{array}$} & 0 & 1058952 & 432228 & 24.98 & 29.98 & 99.95 & 99.95 & \multirow{2}{*}{35.0} & \multirow{2}{*}{41.97} \\
\hline & $4 \mathrm{hrs}$ & 688423 & 250916 & 16.24 & 17.40 & 64.98 & 58.02 & & \\
\hline \multirow{2}{*}{$\begin{array}{l}\text { Thermal / } 60^{\circ} \mathrm{C} / 24 \\
\text { hr/ Solid }\end{array}$} & 0 & 1059419 & 432993 & 25 & 30 & 100 & 100 & \multirow{2}{*}{0.87} & \multirow{2}{*}{0.98} \\
\hline & $\begin{array}{l}24 \\
\mathrm{hrs}\end{array}$ & 1050236 & 428741 & 24.78 & 29.71 & 99.13 & 99.02 & & \\
\hline \multirow{2}{*}{$\begin{array}{l}\text { Photo/1.2 million } \\
\text { lux hrs fluorescent } \\
\text { light } / 200 \mathrm{~W} / \mathrm{m}^{2} \text { of } \\
\text { UV/7 days }\end{array}$} & 0 & 1059424 & 432415 & 25.00 & 30.00 & 100 & 100 & \multirow[b]{2}{*}{10.11} & \multirow[b]{2}{*}{11.95} \\
\hline & $\begin{array}{l}7 \\
\text { Days }\end{array}$ & 952248 & 380728 & 22.47 & 26.41 & 89.88 & 88.04 & & \\
\hline
\end{tabular}


<smiles>O=C(O)c1cn(C2CC2)c2cc(N3CCNCC3)c(F)cc2c1=O</smiles>

Figure 1: structure of Ciprofloxacin $\mathrm{HCl}$<smiles>CCS(=O)(=O)CCn1c([N+](=O)[O-])cnc1C</smiles>

Figure 2: structure of Tinidazole

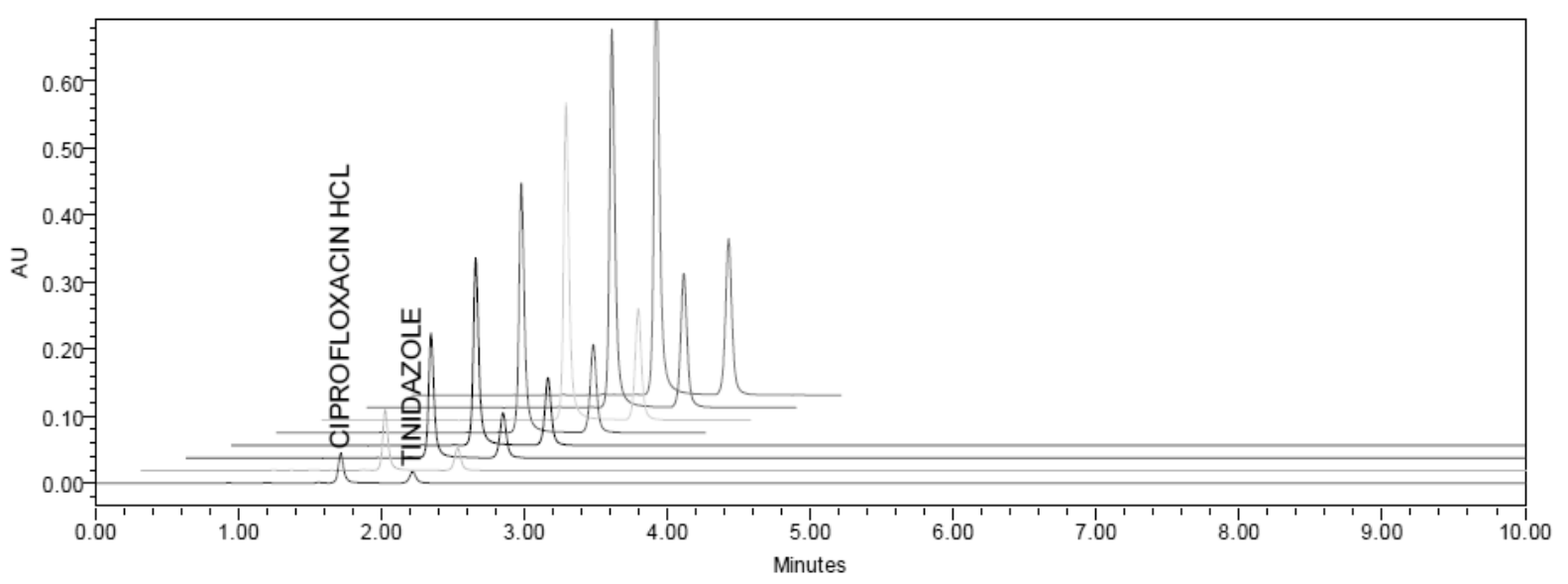

Figure 3: Linearity chromatogram of mixed standard solution of Ciprofloxacin $\mathrm{HCl}(25 \mu \mathrm{g} / \mathrm{ml} \mathrm{Rt} 1.71$ $\mathrm{min})$ and Tinidazole $(30 \mu \mathrm{g} / \mathrm{ml}$ Rt $2.23 \mathrm{~min})$ by RP-UPLC method.

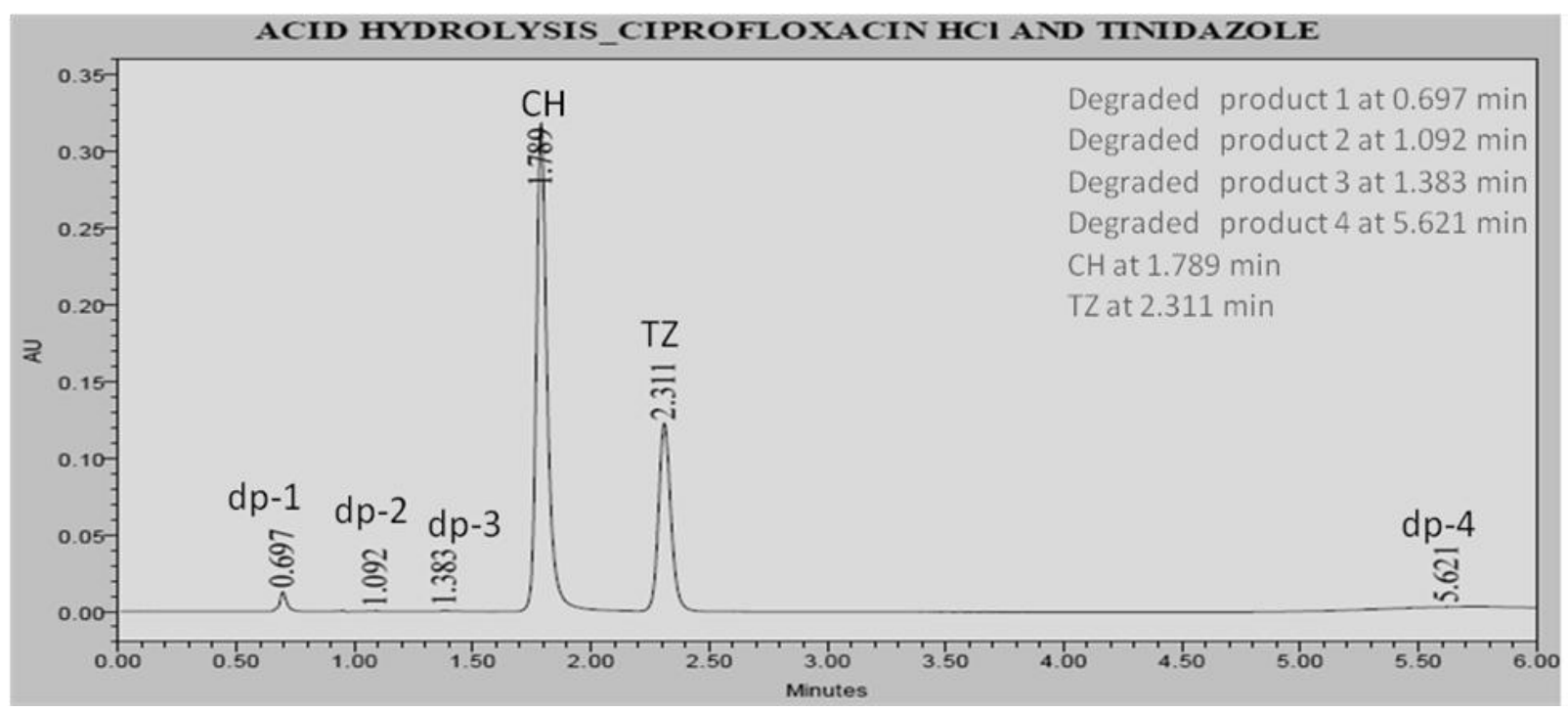

Figure 4: Chromatogram of $\mathrm{CH}$ and $\mathrm{TZ}$ of drug product after $4 \mathrm{hrs}$ degradation in $0.1 \mathrm{~N} \mathrm{HCl}$ at $70 \pm 2{ }^{\circ} \mathrm{C}$ in dark in reflux condition. 
Development and validation of stability indicating method for simultaneous estimation of...

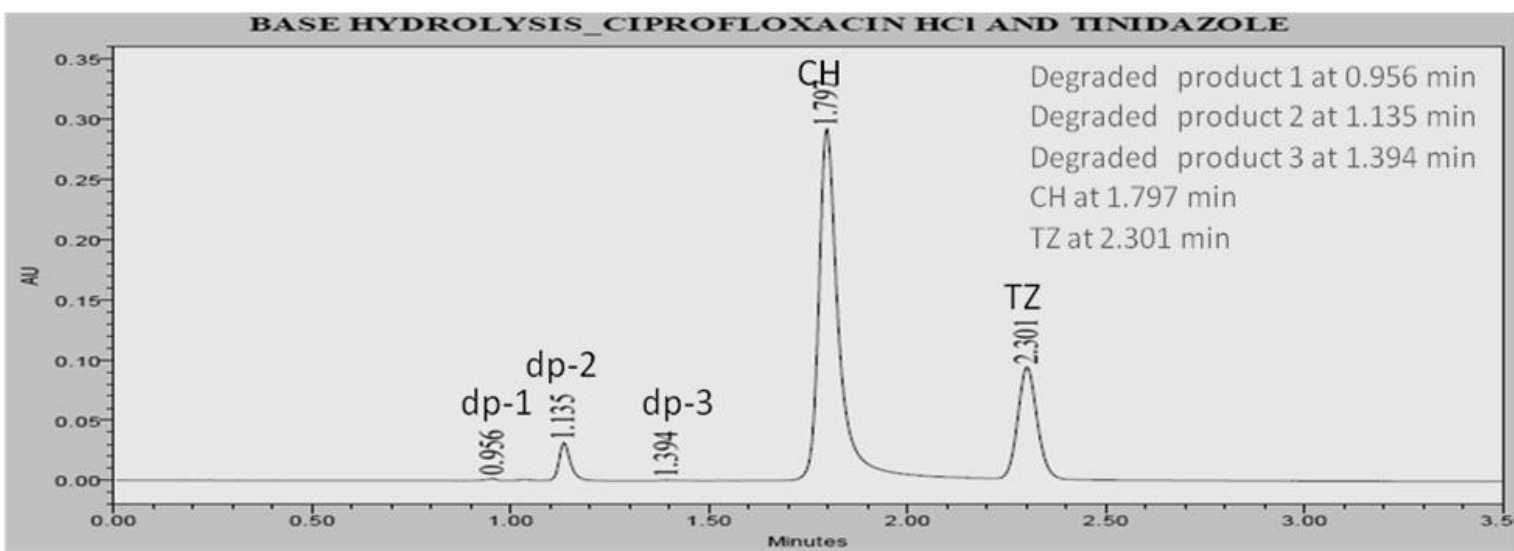

Figure 5: Chromatogram of $\mathrm{CH}$ and $\mathrm{TZ}$ of drug product after 4 hrs degradation in $0.1 \mathrm{~N} \mathrm{NaOH}$ at $70 \pm 2$

${ }^{\circ} \mathrm{C}$ in dark in reflux condition.

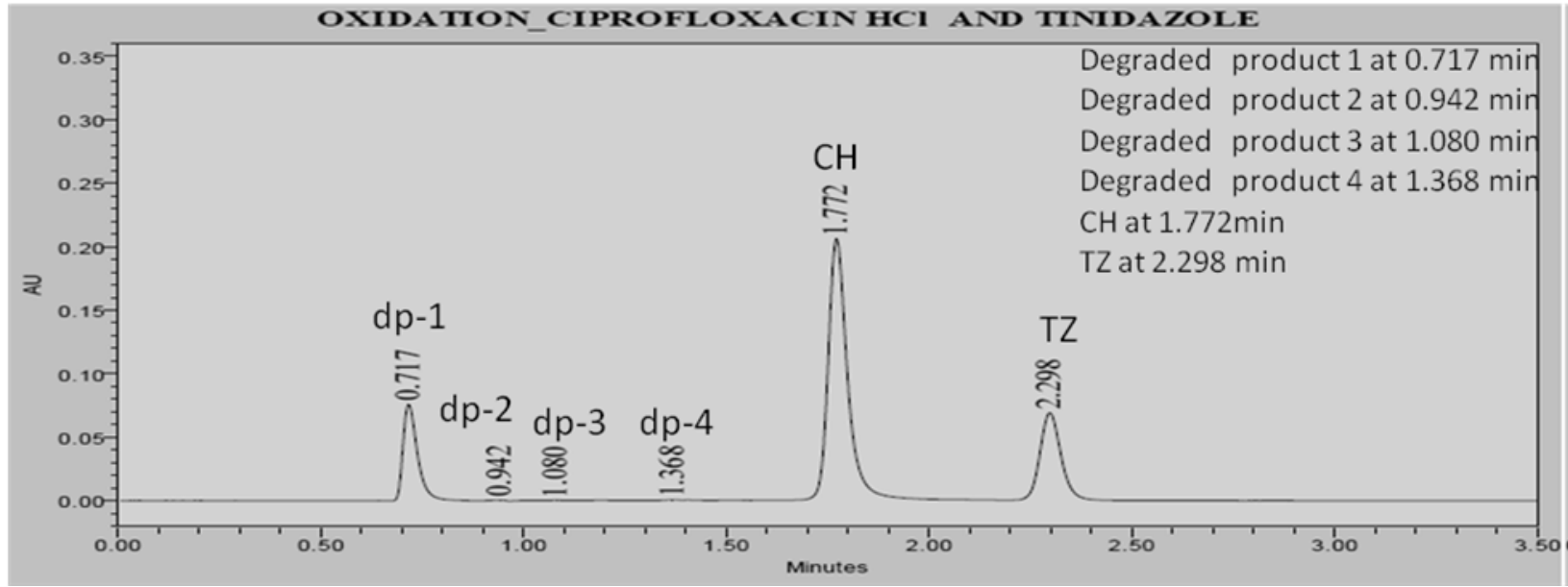

Figure 6: Chromatogram of $\mathrm{CH}$ and $\mathrm{TZ}$ of drug product after $1 \mathrm{hr}$ degradation in $3 \% \mathrm{H}_{2} \mathrm{O}_{2}$ at $70 \pm 2{ }^{\circ} \mathrm{C}$ in dark in reflux condition.

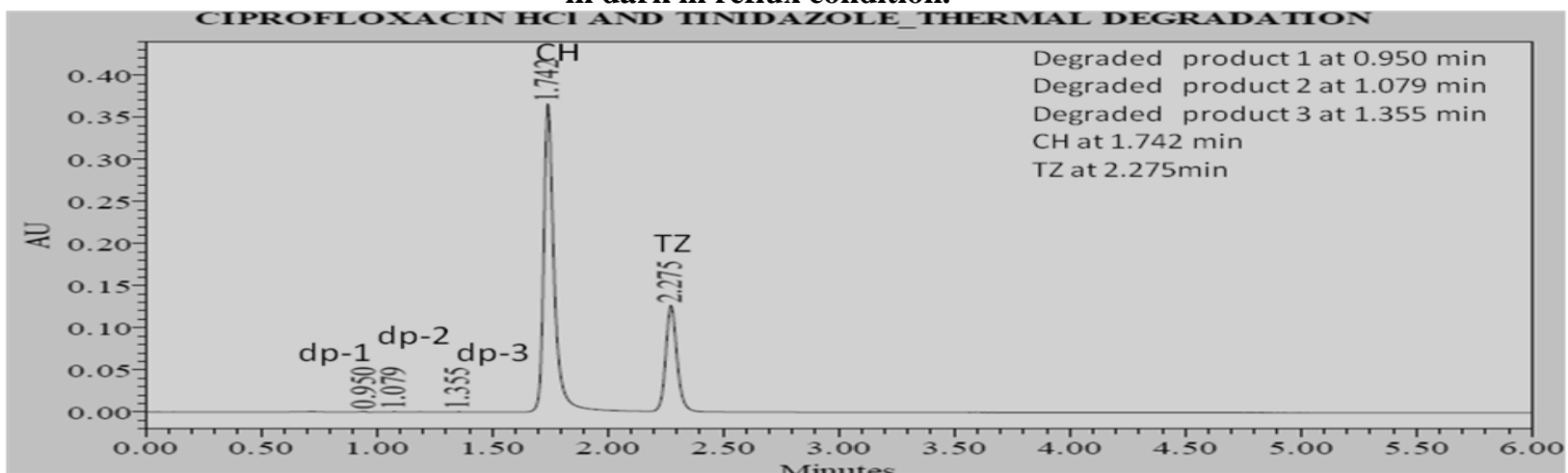

Figure 7: Chromatogram of $\mathrm{CH}$ and $\mathrm{TZ}$ of drug product at $60^{\circ} \mathrm{C}$ for about $24 \mathrm{hrs}$

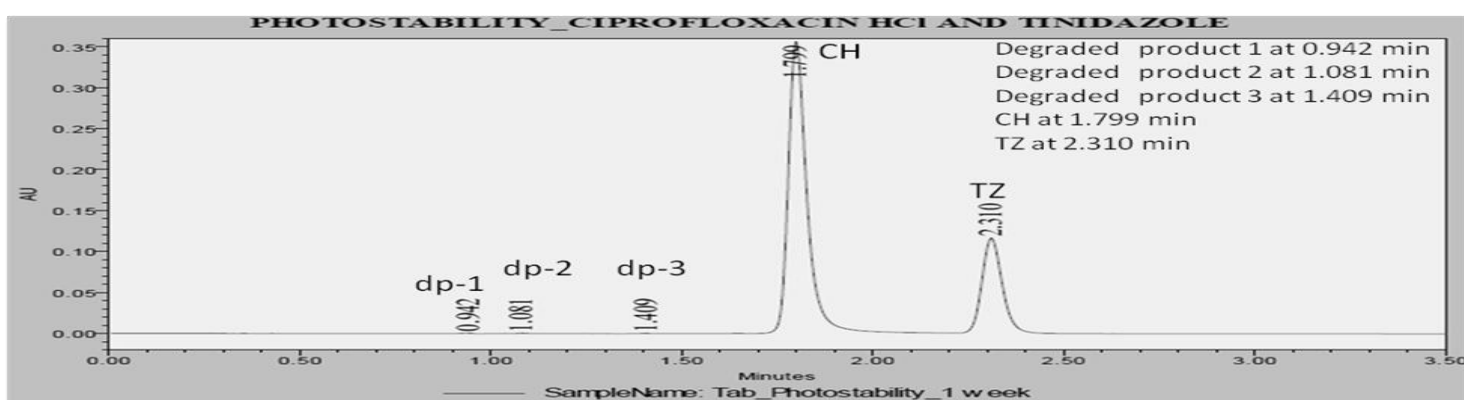

Figure 8: Chromatogram of $\mathrm{CH}$ and $\mathrm{TZ}$ of drug product exposed to 1.2 million lux hrs fluorescent light and $200 \mathrm{~W} / \mathrm{m} 2$ of $\mathrm{UV}$ for about 7 days. 